\title{
INANGAHUA EARTHQUAKE 1968
}

Many years of difficult and costly work on improving and sealing the state highway system in the Inangahua and Buller Gorge areas was virtually ruined in a few seconds by the earthquake of 24 May 1968.

The earthquake caused severe and extensive damage to highways, bridges and culverts, with the major damage centred at Inangahua Junction and extending on No. $6 \mathrm{~S} . \mathrm{H}$. from about Eight Mile Creek in the Upper Buller Gorge to. Windy Point in the Lower Buller Gorge and on No. $69 \mathrm{~S} . \mathrm{H}$. from Inangahua Junction to Cronadun. On No $67 \mathrm{~S} . \mathrm{H}$. there was extensive cracking and deformation of the sealed surface between Westport and Mokihinui and several large land slides on the Karamea Bluff section. On No. $7 \mathrm{~S} . \mathrm{H}$. there were some slumps and dropouts on the Reefton Saddle but apart from this, damage on this State Highway, the Coast Road section of No. $6 \mathrm{~S} . \mathrm{H}$. and No. $65 \mathrm{~S} . \mathrm{H}$. was comparatively light.

On No. $6 \mathrm{s.H.}$ in the Upper Buller Gorge there was very little damage between. Eight Mile Creek and Red Jackets but from Red Jackets to the foot of Duhlin Terrace R.M. $170.80-172.5$ there were a number of large land slides in crushed or shattered granite that covered the road for full width and in some cases reached for over 500 feet from skyline to river level. First reports from an air reconnaissance indicated that long lencths of the road had been destroyed but later when the road shelf was uncovered it was found that there were only a few short lengths where the original full road width was not intact. Opposite the foot of Dublin Terrace on the south side of the Buller River a large rock and rubble avalanche swept over 2000 feet into the Buller River and about 350 feet up the opposite bank to above road level before settling down to dam the Buller to a height of between $60^{\circ}$ - $80^{\prime}$ above normal. The Buller River was backed up for about 4 miles but early on the 25 th May'it broke over the top of the dam and gradually cut down without causing any serious flooding in its lower reaches.

There were no large slips on the road over Dublin Terrace between R.M. $172.5-174.5$ but on the crushed and shattered granite between R.M. 174.5 - 175.5 practically the whole mile length of road was fully covered by massive and continuous slips of rock, rubble and timber. Between Deadmans Creek and the Lyell slips were not extensive but a large sip in Lyel1 Creek above the highway bridge caused a large washout in the bridge approach fill.

There were minor slips only between the Lyel1 and Iron Bridge except for a large slip at White Creek which completely covered a new reinforced. concrete box culvert and filled the stream bed above with a mass of twisted timber, rock and rubble. Between Iron Bridge and Bens Creek slips and mudflows were practically continuous with one exceptionally large rotational landslide in papa near Van Vugts where a 20 chain leneth of sealed road had been swept bodily 40 - 50 feet downhill.

+ Ministry of Torks

Restient Mngineer, Jestport. 
Prom Dens Creok to Inangahua there were several 1 arge and numerous smal. slips and long lengths of the sealed surfaces were badly damaged by slumps and cracks. Between Spring Creek and the Dee hill a rotational landslide had shifted the road about 40 feet out from its original aligninert over about a 10 chain length. At Inangahua Junction a 1 arge wet slip studded with timber covered the highway and there was extensive full width road slumping over a 50 chain length below Inangahua Junction and $\operatorname{lar}_{\mathrm{r}} \mathrm{e}$ and dangerous slips from broken limestone over Goodyers Hil1.

In. the Whitecliffs area the high bluffs of limestone overlying papa were badly shattered and large landslides wrecked Cave Creek bridge and substantially covered the highway over a 50 chain length including the recently constructed Whitecliffs Creek culvert. It was necessary to abandon the highway over this section and relocate a new road in the river bed clear of the unstable cliffs and wet slips. Between Whitecliffs and Berlins there were numerous slips including several large mud flows that continued to pour over the highway for some days after the earthquake. One of the mud flovs carried a number of $80^{\prime}$ long white pine trees $3-4$ feet in diameter at the butts. The highway over this section was badiy deformed by large transverse and longitudinal cracks, some over one foot in width and $4-5$ feet deep and numerous slumps that varied up to 5 feet in depth.

From Berlins to Windy Point large slips, slumping and cracking continued but to a 16 sser extent. On No. 7 S.H. apart from a large dropout and slumping on the Reefton Saddle there was little damage while on No. $65 \mathrm{~S} \cdot \mathrm{H}$. there were minor slips only. On No. $67 \mathrm{~S} . \mathrm{H}$. Westport Karamea there was extensive damage to the sealed surfaces by cracking and slumping mainly between Westport and Granity and on the Karamea Bluff section a large landslide engulfed and destroyed a $40^{\prime} \mathrm{R} . \mathrm{S} . J$. bridge over Sandal Creek. There were also several other large slips between Konini and Corbyvale. No. 69 S.H. Inangahua - Reefton was badly damaged by numerous large cracks and slumps over most of the length between Inangahua and Cronadun and a large papa slip blocked the highway over about a 10 chain length at Oweka Bluffs.

Slips and landslides varied from large rock falls to mudflows and those that affected the highways varied with the rock and soil type in the highwoy cuttings and in general the size of the slips on highways was related to the height and slope of constructed batters. Some consideration could be possibly made in the future to allow for rounding off or benching in the design of batters for highway cuttings but any design outside the conventional could involve high costs in difficult country. Some of the slips in rock cuttings could be partly attributed to the blasting methods used in road widening. In such cases, mainly because of the difficulty in gaining access to the top of the batters the method used was to dril1 horizontal or breast holes at road level and shoot from the bottom. This method often resulted in considerable overbreak and shattering of ground behind the batter Iine. An improved method would be the use of line drilling in the construction of rock cuttings and I consider that if Iine drilling vere used more extensively it would reduc the risk of earthquake movement causing rock fills.

The total assessed quantity of slip material that had to be cleared from highways as a result of the earthqualce exceeded 400,000 cubic yards. On Nos。 6,67 and 69 state Highways over 20 miles of originally sealed surface has to be restored by building up and reshaping with river metal filling and constructing a new basecourse and sealing. The estimated quantities of materials required for this restoration work are: 







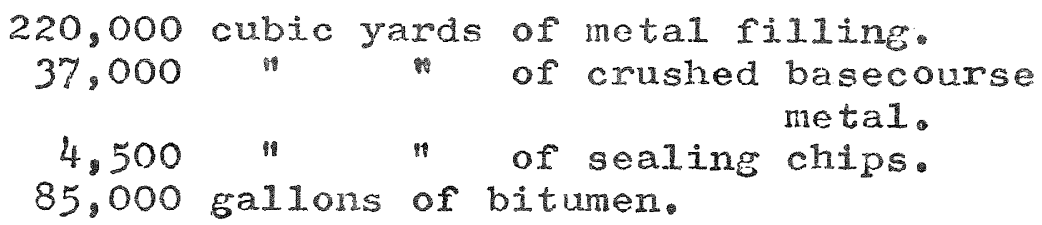

Damage to culverts was prevalent on all highways and the damage varied with the type of formation in which the culvert was situated. Pipes were pulled apart by side movements of the formation or displaced both vertically and horizontally and wingwalls damaged or displaced by earth pressure. One of our early problems in restoring damage was the lack of water control caused by damaged or collapsed culverts. The pattern of cracking and deformation of sealed pavements varied but was related to changes in subgrade materials and between cutting and filling formations or poorly compacted shoulders and side fillings. Better and complete compaction of highway fillings and the construction of properly designed batters and the removal of poor foundation material under fillings would considerably reduce the risk of cracking by earthquake movement.

Traffic was seriously disrupted as a result of the earthquake and it was ten weeks before the Upper Buller Gorge section of No. 6 S.H. was reopened and three weeks before the Lower Buller Gorge Section of No. 6 S.H. and No. 69 S.IS. Inangahua - Reefton were reopened. No. 67 S.H. Westport - Karamea was closed at the Bluff section for 3 days but the Coast Road section of No. 6 S.H. No. 7 S.H. Waipara - Reefton and No. $65 \mathrm{~S} . \mathrm{H}$. Murchison - Springs Junction were all kept open.

\section{Bridges}

State Highways in the area were rendered impassable mainly because of blockages by slips and damage to road surfaces rather than by structural damage to bridges. Settling at abutments and approach fills was prevalent and the severity increased with a greater depth of unconsolidated material. Settling at bridge abutments varied from about 5 feet to a for inches.

Serious structural damage to bridges was limited to a radius of 5 miles from Inangahua Junction. Detailed inspections of all highway structures were made as soon as possible after the earthquake and although it was found that a number of structures near Inangahua had received quite serious damage there were none that were unsafe and all highway structures were quickly made serviceable for maximum highway loading.

Concrete bridges were damaged at abutment headwalls, at abutment beam and pier beam connections and between piers and piles or cylinders. There was also damage to piers and abutments due to settlement of foundations. Bridges with steel girders on concrete abutments and piers had H.D. bolts sheared or bent and headwalls damaged by impact from girder ends, bridges of R.S.J's on hardwood had abutment caps pushed off piles. Large concrete culverts had wingwalls demolished by high earth pressure.

The main deficiencies in design were lack of resistance to earth loading in abutments and wingwalls and inadequate strength in abutment headwalls to resist impact from end of beams, or inadequate provision for greater span displacements. The main construction fault has been the lack of proper preparation of construction joints. 


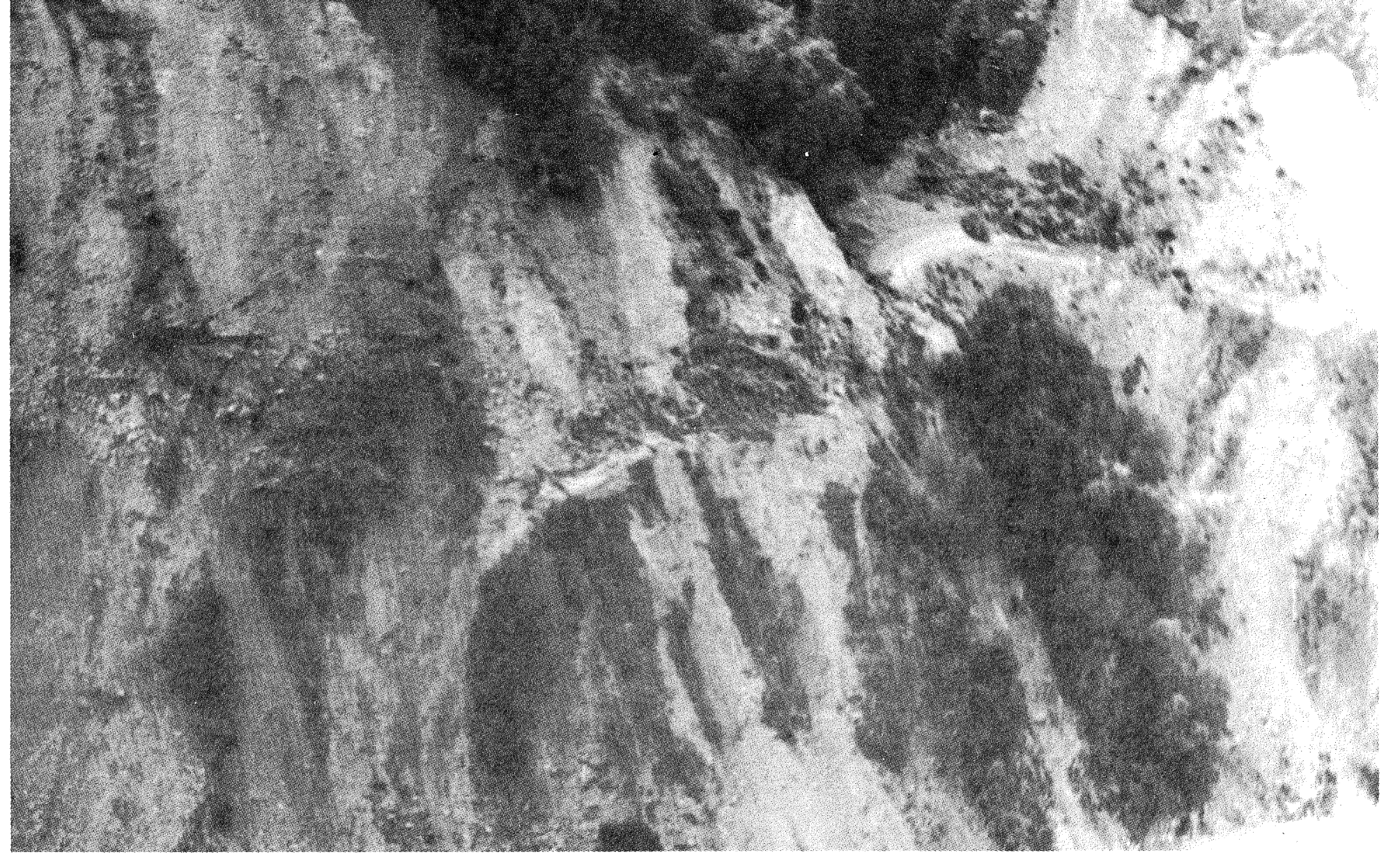

S.H.G R.M. $175.00 \mathrm{M}$

Typical slips: Eight Mile Ck. - Lyell Ck. Section 


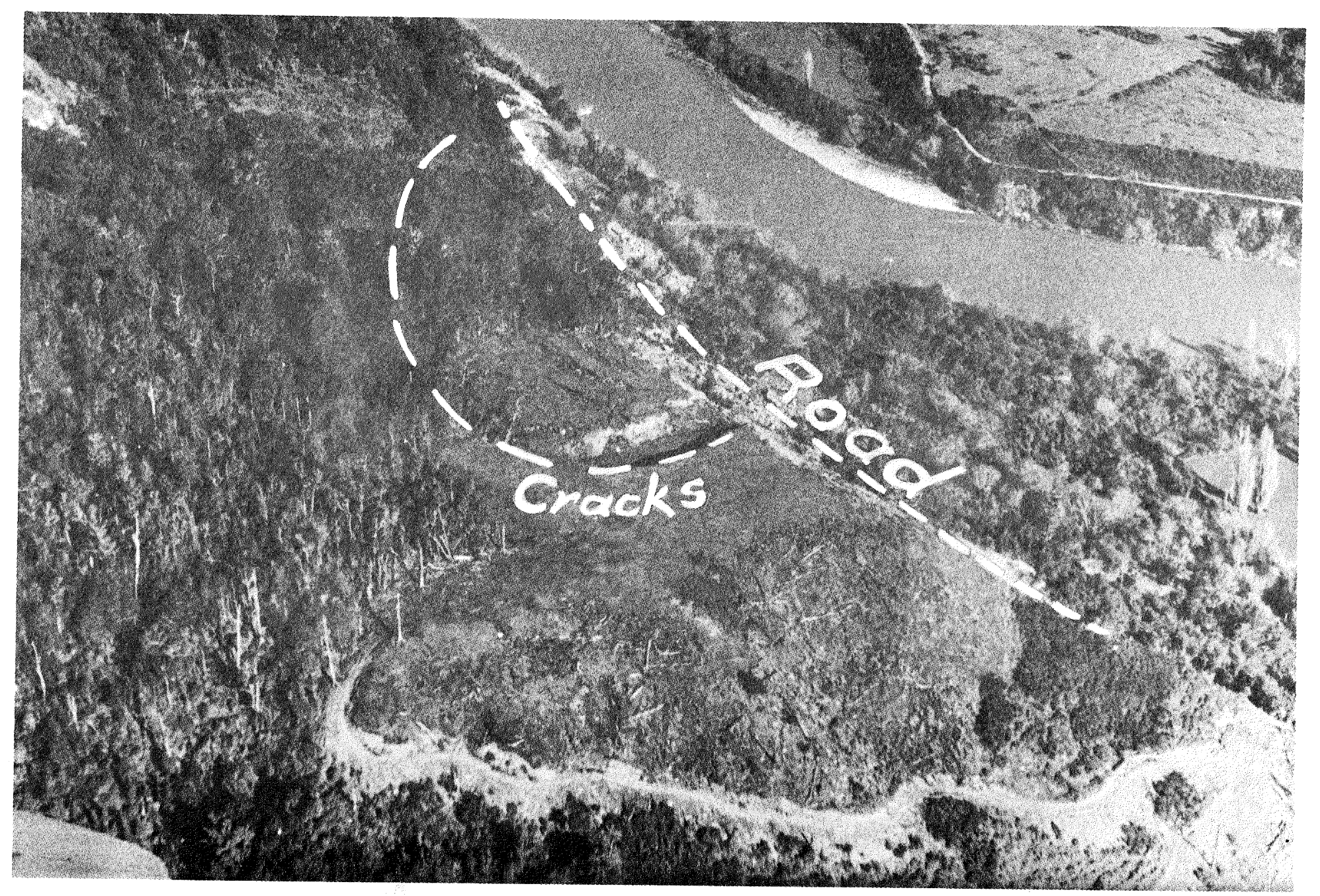

S.H.G. R.M. $178.80^{\mathrm{m}}$

Slip at Van Vugh's showing cracks in terrain 


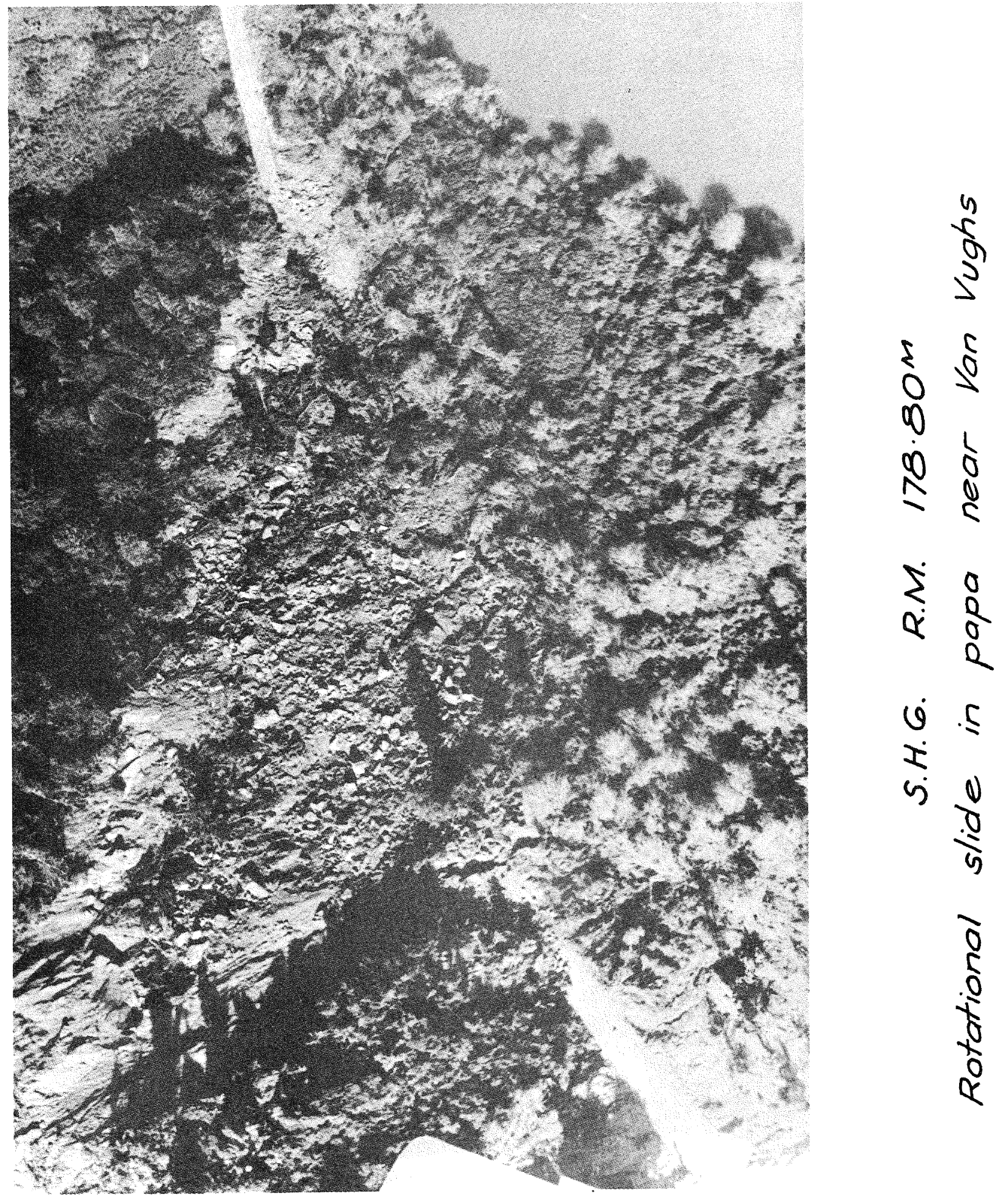




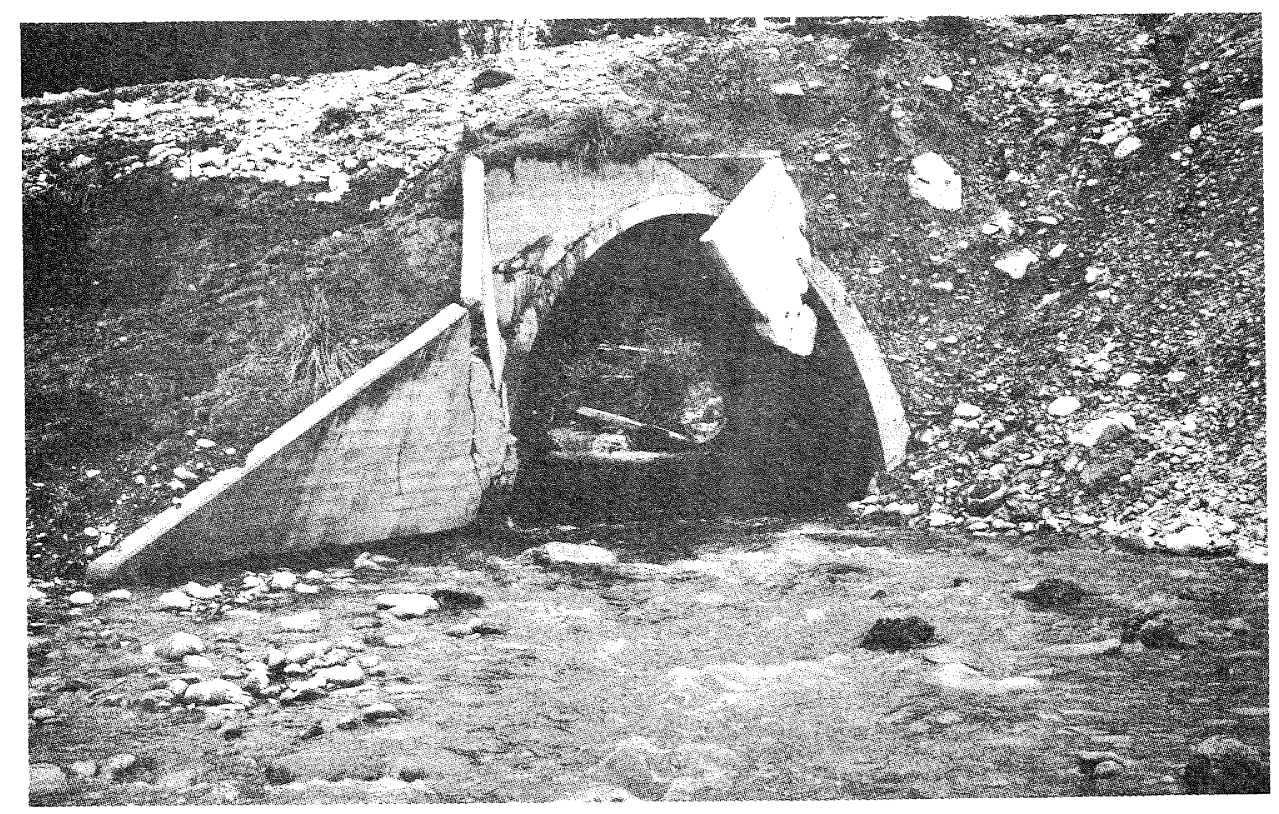

\author{
S.H.6 R.M. 182.55 \\ De Filippi Culvert damage
}

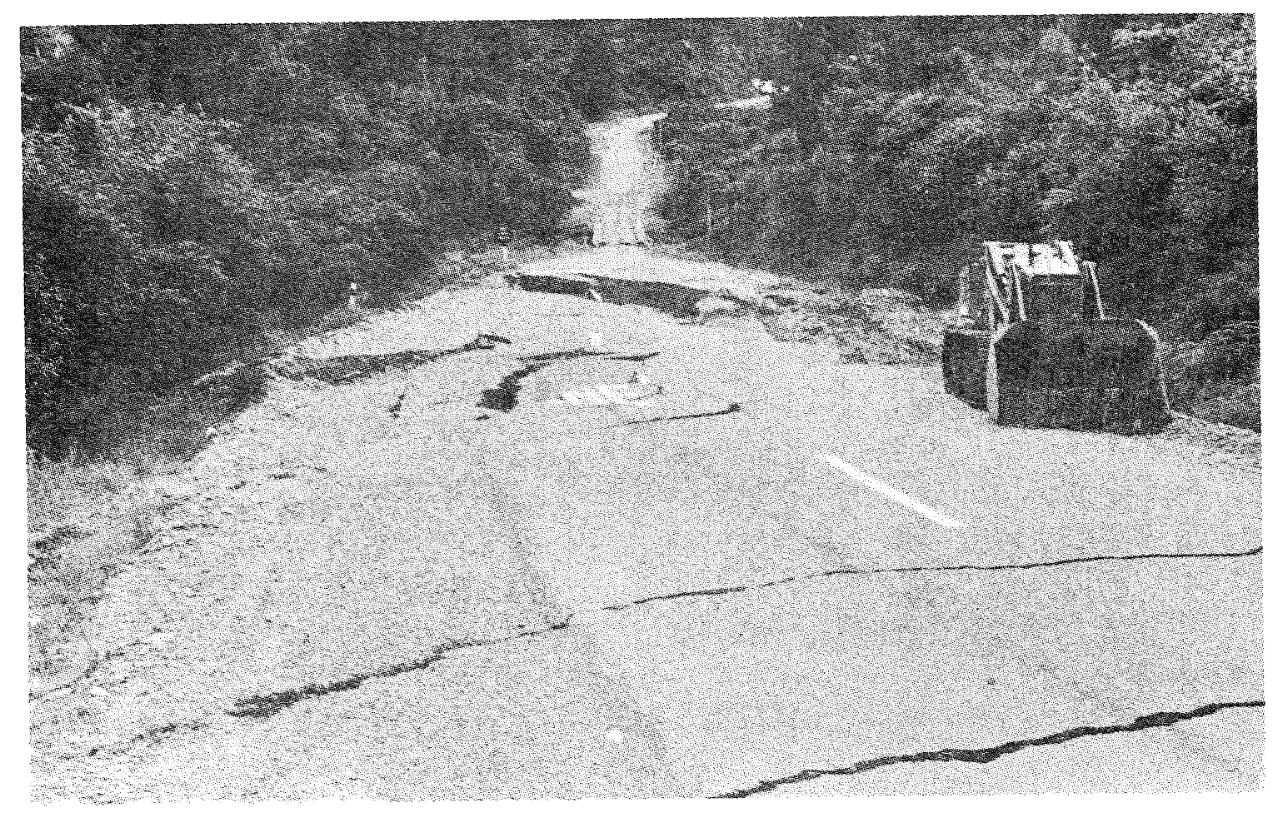

S.H.G R.M. $193.80 \mathrm{M}$.

Coal Creek approaches: Road subsidence 




\section{S.H.6. R.M $190.00 \mathrm{M}$}

Rockfalls and landslides of Whitediffs. 

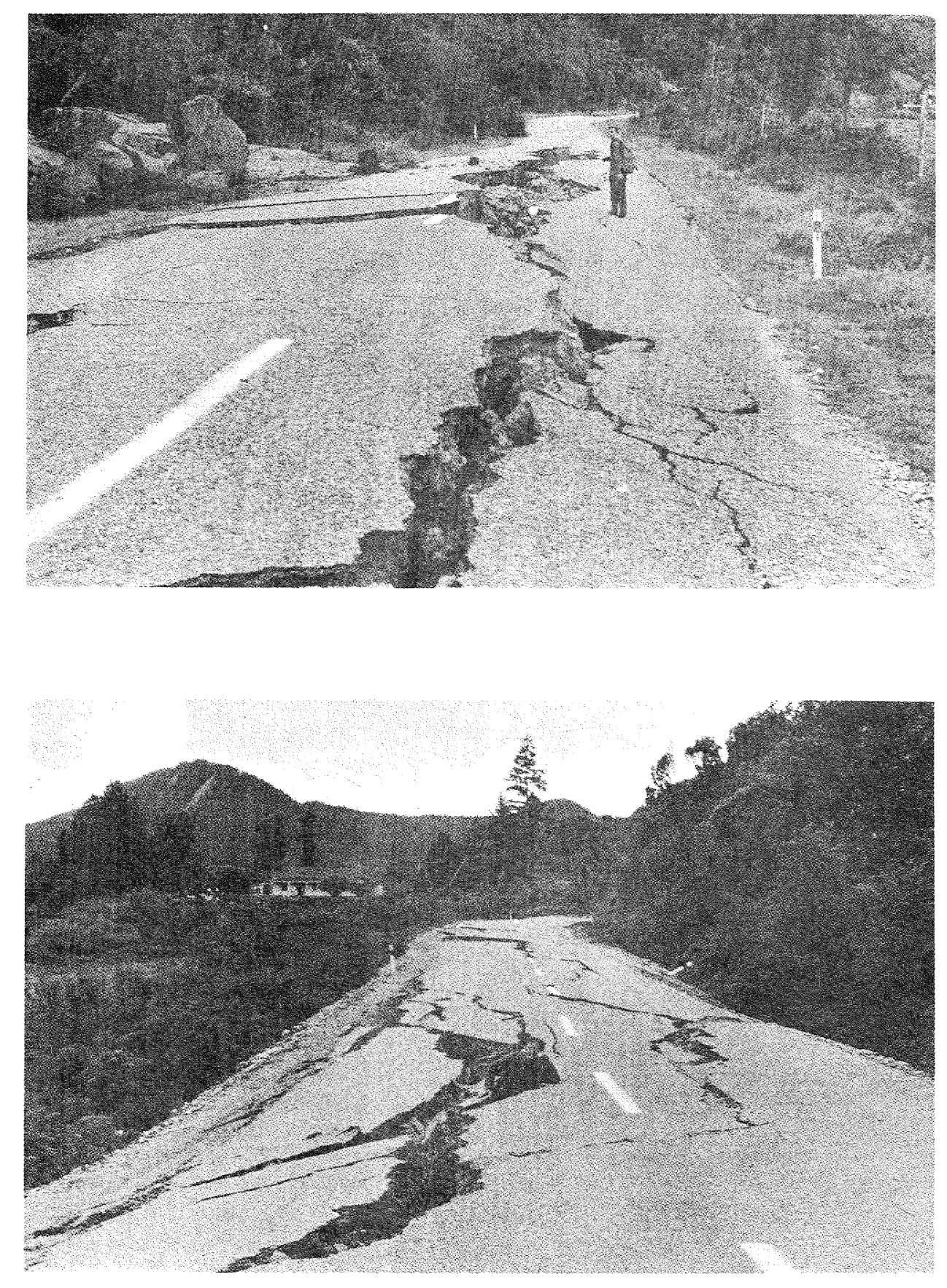

S.H.6 R.M. $192.00 \mathrm{M}$.

Typical highway damage at Rocklands. 




S.H.G R.M. $196.90 \mathrm{M}$.

Rock and clay slip at Stitt's Bluff. 